\title{
DETERMINATION OF BEARING CAPACITY OF BLACK COTTON SOIL STABILISED WITH TERNARY BLEND FOR FIELD APPLICATION
}

\author{
Uma. G. Hullur \\ Assistant professor Department of Civil Engineering, \\ K.L.S. Gogte Institute of Technology Belagavi, Karnataka, India. \\ Dr. S. Krishnaiah \\ Professor Department of Civil Engineering, \\ Jawaharlal Nehru Technological University, Anantapur, Andhra Pradesh, India. \\ Dr. K. B. Prakash \\ Principal, Government Engineering College \\ Haveri, Karnataka, India.
}

\begin{abstract}
Expansive soils are problematic soils, due to the performances of their clay mineral constituent makes that they exhibit the shrink-swell characteristics of the soil. The direct engineering application of expansive soils make inappropriate to use them in natural form. Hence in an attempt to make them more feasible for construction purposes, numerous materials and techniques have been used to stabilise the soil. In this particular study, the additives and techniques applied for stabilising expansive soils will be focused with respect to their efficiency in improving the engineering properties of the soils. Thus the effective application of improving the characteristics of expansive soil by using different stabilizers in ternary blend for their structural application is studied [6].
\end{abstract}

Key words: Black Cotton Soil, Ternary Blend, Stabilisation, Cement, Flyash, Metakaolin, Bearing capacity.

\section{INTRODUCTION}

The physical properties of Black Cotton Soil (BCS) vary from place to place. At liquid limit, the volume change is greater and results in swelling pressure are also high. Generally, BCS has very low bearing capacity and high swelling and shrinkage characteristics. Water lubricates the soil particles and makes the inter-particle mechanical interlock unstable. Swelling pressure is a major cause of failure in foundations supported by BCS [4]. Moreover, saturated BCS have lower bearing capacity and higher degree of compressibility, ultimately resulting in settlements. A number of failures of earth dams, tunnels, hydraulic structure, foundations and road embankments have occurred due to swelling problems of these soils [2]. However, the lack of space, resources and other related issues make it necessary to build structures supported on BCS. Therefore, usually the most practical and feasible option left is to improve the characteristics of the BCS by stabilisation.

\section{LITERATURE REVIEW}

Andromalos et al. (2000): Studied the strength and mechanical properties of the cement stabilized soil. They are related with the effectives of the cement and with the mineralogical composition of a clayey soil.

Koncagül et al. (1999): Studied on clayey soils which from montmorillonite (bentonite) or kaolinite (kaolin) mineral. They showed good performance under working load. Moreover, impact of the minerals on hydration of cement and hardening process are also different.

Bell (1978): Showed Kaolin had small impact on hardening process when compared to bentonite, which requires large amounts of cement to obtain proper Strength properties.

ErdalCokca (2001): Studied on effect of Flyash on expansive soil, Flyash consists of hollow spheres of silicon, aluminium and iron oxides and unoxidized carbon. There are two classes of flyash, they are class $\mathrm{C}$ and class $\mathrm{F}$. The former is produced from burning anthracite or bituminous coal and the latter is produced from burning lignite and sub bituminous coal. Both the classes of fly ash are having good cementitious property, which are defined as siliceous and aluminous materials. Thus, Flyash can provide divalent and trivalent cations $(\mathrm{Ca} 2+, \mathrm{Al} 3+, \mathrm{Fe} 3+$ etc. $)$ under ionized conditions that can promote flocculation of dispersed clay particles. Thus, expansive soils can be stabilized effectively by cation exchange process using flyash. He carried out test using Soma Flyash and Tuncbilek flyash. He prepared specimens of expansive soil treated with0-25\%. After curing the specimens cured for 7days and 28 days, The Oedometer, free swell tests experimental findings confirmed that the plasticity index, activity and swelling potential of the samples decreased with increase in percentage of stabilizer and curing time. The optimum content of flyash in decreasing the swell potential was found to be $20 \%$. He concluded that both high -calcium and low calcium class $\mathrm{C}$ fly ashes can be recommended as 
effective stabilizing agents for improvement of expansive soil properties.

Pandian et.al. (2002): The CBR characteristics of the black cotton soil were studied using the effect of two types of fly ashes Raichur fly ash (Class F) and Neyveli fly ash (Class C). The fly ash content was increased from 0 to $100 \%$. Generally, the CBR/strength is contributed by its cohesion and friction. The low CBR of BC soil is attributed to the inherent low strength, which is due to the dominance of clay fraction. On addition of fly ash to $\mathrm{BC}$ soil increases the CBR of the mix up to the first optimum level due to the frictional resistance from fly ash in addition to the cohesion from BC soil. Thus the variation of $\mathrm{CBR}$ of fly ash-BC soil mixes can be attributed to the relative contribution of frictional or cohesive resistance from fly ash or BC soil, respectively.

Phanikumar and Sharma (2004): A similar study was carried out and the effect of fly ash on engineering properties of expansive soil through an experimental programme was investigated. The effect on parameters such as free swell index (FSI), swell potential, swelling pressure, plasticity, compaction, strength and hydraulic conductivity of expansive soil was studied. The expansive soil was treated with flyash contents of $0,5,10,15$ and $20 \%$ by dry weight and they inferred that increase in flyash content reduces plasticity characteristics and the FSI was reduced by about $50 \%$ by the addition of $20 \%$ fly ash. The hydraulic conductivity of expansive soils mixed with flyash decreases with an increase in flyash content, due to the increase in maximum dry unit weight with an increase in flyash content. When the flyash content increases there is a decrease in the optimum moisture content and the maximum dry unit weight increases. Hence the expansive soil is rendered more stable. The undrained shear strength of the expansive soil mixed with flyash increases with the increase in the ash content.

Salvado (1995): Stated Metakaoilin is a highly pozzolanic and reactive and supplementary cementatious material. It is unique in that it is neither the by-product of an industrial process nor is it entirely natural. Metakaolin is derived from naturally occurring mineral and is manufactured specially for cementing applications; it is refined kaolin clay that is fired (calcined) under carefully controlled conditions to create an amorphous alumina silicate that is reactive in concrete and is obtained by calcination of the kaolinitic clay at temperatures $600-800$ oC which when used as stabilizer reduces the volume change.

\section{MATERIALS AND METHODOLOGY}

In this particular study Cement, Flyash and Metakaolin are blended with Black Cotton soil and the Shear parameters are studied which can be used in weak foundation stabilization so that the bearing capacity of the soil can be improved. The chemical compositions of the stabilizers are as follows.

Table: 1 Chemical composition of stabilisers

\begin{tabular}{|l|l|l|l|}
\hline Property & Cement & Flyash & Metakaolin \\
\hline $\mathrm{SiO} 2$ & $21.9 \%$ & $59.94 \%$ & $54.3 \%$ \\
\hline $\mathrm{A} 12 \mathrm{O} 3$ & $6.9 \%$ & $22.87 \%$ & $38.3 \%$ \\
\hline
\end{tabular}

\begin{tabular}{|l|l|l|l|}
\hline $\mathrm{Fe} 2 \mathrm{O} 3$ & $3 \%$ & $4.67 \%$ & $4.28 \%$ \\
\hline $\mathrm{CaO}$ & $63 \%$ & $3.08 \%$ & $0.39 \%$ \\
\hline $\mathrm{MgO}$ & $2.5 \%$ & $1.55 \%$ & $0.08 \%$ \\
\hline $\mathrm{SO} 3$ & $1.7 \%$ & $0.35 \%$ & $0.03 \%$ \\
\hline
\end{tabular}

The geotechnical properties of the Black cotton soil are experimentally determined in the laboratory

Table: 2 Properties of $\mathrm{BC}$ soil.

\begin{tabular}{|l|l|l|}
\hline $\begin{array}{l}\text { S1 } \\
\text { No }\end{array}$ & Laboratory Tests & Results \\
\hline 1 & Liquid Limit (\%) & 87.2 \\
\hline 2 & Plastic Limit (\%) & 52.06 \\
\hline 3 & Plasticity Index & 35.14 \\
\hline 4 & $\begin{array}{l}\text { Optimum Moisture } \\
\text { content(OMC)\% }\end{array}$ & 23 \\
\hline 5 & $\begin{array}{l}\text { Max Dry } \\
\text { Density(MDD)KN/M3 }\end{array}$ & 13.826 \\
\hline 6 & Cohesion (C ),KN/M2 & 29.418 \\
\hline 7 & $\begin{array}{l}\text { Angle of internal friction( } \Phi \\
\text { )o }\end{array}$ & 18 \\
\hline 8 & UCS KN/M2 & 127.478 \\
\hline 9 & CBR Value & $6.13 \%$ \\
\hline & Unsoaked 2.5mm & $2.18 \%$ \\
\hline & $5.0 m m$ & $3.65 \%$ \\
\hline & Soaked 2.5mm & $2.06 \%$ \\
\hline & $5.0 m m$ & CH \\
\hline 10 & $\begin{array}{l}\text { Classification of soil } \\
\text { (Casagrande plasticity chart } \\
\text { USCS) }\end{array}$ & \\
\hline & & \\
\hline
\end{tabular}

The above table shows the behaviour and the properties of the black cotton soil.

\section{RESULTS AND DISCUSSIONS}

This soil further mixed with different percentages of the stabilizers and the proctor test was carried to know the optimum value of each stabilizer. The results are given in Table: 3

Table: 3 Laboratory test results for soil blended with individual stabilizers.

\begin{tabular}{|c|c|c|c|c|c|c|c|c|c|}
\hline & \multicolumn{3}{|c|}{ Cement } & \multicolumn{3}{|c|}{ Flyash } & \multicolumn{3}{|c|}{ Metakaolin } \\
\hline & $8^{\circ}$ & $\stackrel{d}{0}_{0}^{0}$ & 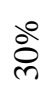 & $8^{\circ}$ & 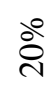 & bे & $\stackrel{8}{0}$ & ঠి & 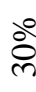 \\
\hline $\begin{array}{l}\text { Dry } \\
\text { density } \\
\text { KN/M3 }\end{array}$ & $\begin{array}{l}2 \\
\stackrel{2}{2}\end{array}$ & $\begin{array}{l}\hat{\&} \\
\infty \\
\dot{I}\end{array}$ & $\begin{array}{l}\frac{m}{n} \\
\stackrel{-}{ \pm}\end{array}$ & $\begin{array}{l}\hat{\curvearrowright} \\
\text { ñ }\end{array}$ & $\begin{array}{l}\overline{0} \\
\stackrel{n}{2}\end{array}$ & $\begin{array}{l}= \\
\bar{\sigma} \\
\dot{ \pm}\end{array}$ & 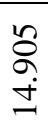 & $\begin{array}{l}\hat{\Omega} \\
\text { ñ }\end{array}$ & 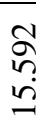 \\
\hline $\begin{array}{l}\mathrm{OMC} \\
\%\end{array}$ & 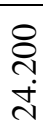 & $\begin{array}{l}\stackrel{8}{8} \\
\text { ¿े }\end{array}$ & $\begin{array}{l}8 \\
8 \\
\text { i } \\
\text { mे }\end{array}$ & $\begin{array}{l}8 \\
8 \\
\text { i }\end{array}$ & $\begin{array}{l}8 \\
8 \\
\text { ¿े }\end{array}$ & $\begin{array}{l}\text { \& } \\
\text { n̊ } \\
\infty\end{array}$ & $\begin{array}{l}8 \\
8 \\
\text { ì }\end{array}$ & $\begin{array}{l}8 \\
8 \\
\stackrel{\imath}{v}\end{array}$ & $\begin{array}{l}8 \\
\text { ¿ } \\
\text { त }\end{array}$ \\
\hline
\end{tabular}




\section{International Journal of Engineering Applied Sciences and Technology, 2020 \\ Vol. 4, Issue 11, ISSN No. 2455-2143, Pages 410-413 \\ Published Online March 2020 in IJEAST (http://www.ijeast.com)}

Studying the behaviour of the black cotton soil, Cement, Flyash, and Metakaolin were mixed with different percentage by dry weight of soil such as $10 \%, 20 \%$ and $30 \%$ and the test were conducted for the different mix proportions to find the optimum values. The procedure or the methodology adopted for determining the mix proportion and the steps to arrive for a ternary blend can be explained in the following steps.

1. Tests were conducted on $\mathrm{BC}$ soil to determine the geotechnical properties.

2. Tests were conducted on $\mathrm{BC}$ soil blended with individual stabiliser with varying percentage such as $10 \%, 20 \%, 30 \%$ and optimum values for dry density were obtained.

3. From the test results it was clear that the maximum MDD for Metakaolin was achieved at $30 \%$ and for cement and flyash the maximum MDD was achieved at $10 \%$,

4. Hence in the ternary blend, minimum amount of the stabiliser to be considered was, the sum of all stabilizers was $10 \%$ and maximum was $30 \%$.

From the above test results, it is clear that the engineering properties of the black cotton soil can be improved by soil stabilization process. Keeping this into consideration the idea of ternary blend which consisted of all the three stabilizers which can be used as an improvement for stabilised soil for the structural application was studied and the experiments were conducted to prove the same. To understand the behaviour of improvement of stabilized $\mathrm{BC}$ soil by using ternary blend, the proctor test was conducted. The results are as shown in Fig: 1

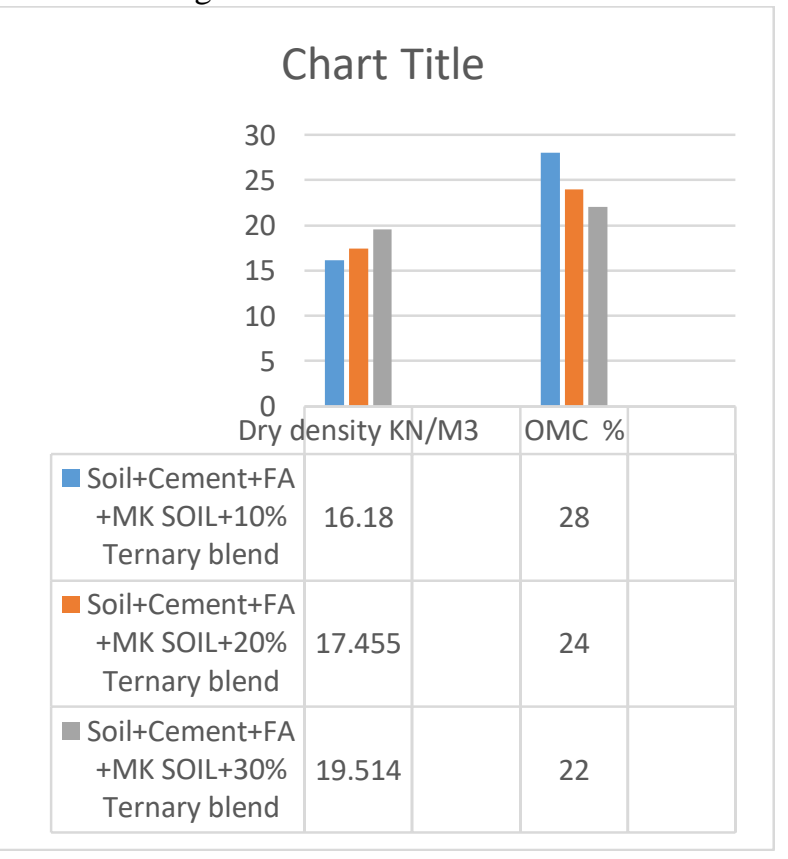

Fig:1 Proctor test results for ternary blended stabilized BC soil.

From the above test results, a bed of $2 \mathrm{mX} 2 \mathrm{mX} 1.5 \mathrm{~m}$ was prepared and a sample for shear strength was extracted. The shear parameters of the stabilized soil were determined by carrying out the direct shear test. The results obtained was used to calculate the SBC of the soil as shown in fig: 3.

Fig: 2 shows the shear parameters of the ternary blended stabilised BC soil.

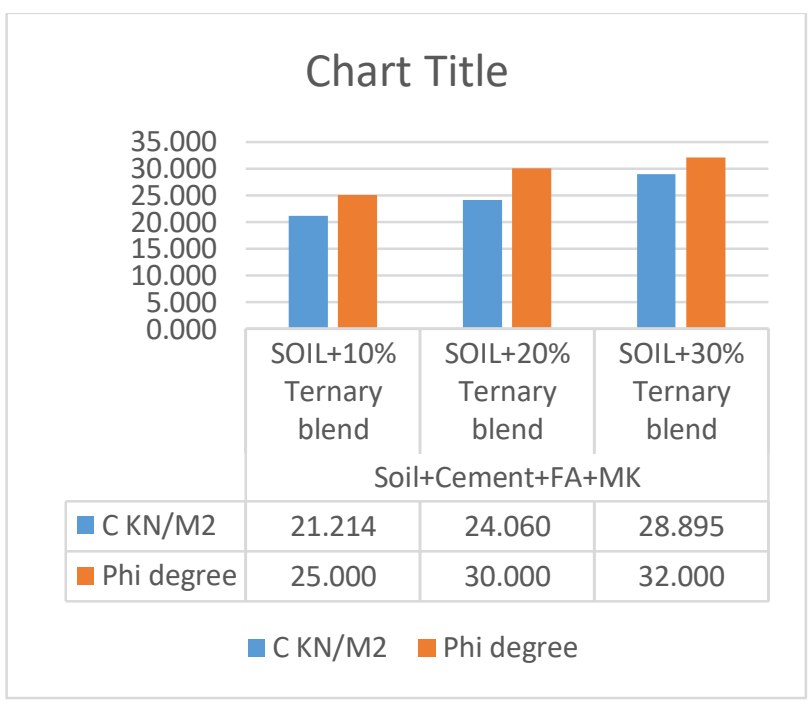

Calculation of bearing capacity of soil: Considering the prepared stabilised BC soil bed of $2 \mathrm{~m} X 2 \mathrm{~m}$ and a depth of $1.5 \mathrm{~m}$

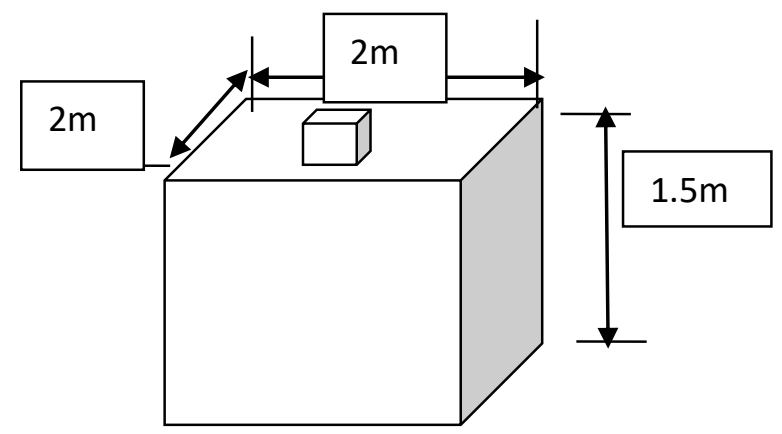

Terzaghi's bearing capacity factors are considered from the below table[ 9 ]

Table 12.1 Bearing capacity factors of Terzaghi

\begin{tabular}{cccc}
\hline$\phi^{\circ}$ & $N_{G}$ & $N_{q}$ & $N \gamma$ \\
\hline 0 & 5.7 & 1.0 & 0.0 \\
5 & 7.3 & 1.6 & 0.14 \\
10 & 9.6 & 2.7 & 1.2 \\
15 & 12.9 & 4.4 & 1.8 \\
20 & 17.7 & 7.4 & 5.0 \\
25 & 25.1 & 12.7 & 9.7 \\
30 & 37.2 & 22.5 & 19.7 \\
35 & 57.8 & 41.4 & 42.4 \\
40 & 95.7 & 81.3 & 100.4 \\
45 & 172.3 & 173.3 & 360.0 \\
50 & 347.5 & 415.1 & 1072.8 \\
\hline
\end{tabular}

$\mathrm{Q}_{\mathrm{u}}=1.3 c \mathrm{~N}_{\mathrm{c}}+\Upsilon \mathrm{D} \mathrm{N} \mathrm{N}_{\mathrm{q}}+0.4 \Upsilon \mathrm{B} \mathrm{N} \mathrm{N}_{\Upsilon}$

$\mathrm{Qu}=1.3 * 21.214 * 25.1+20.710 * 1.5 * 12.7+0.4 * 20.710 * 2 * 9.7$ $=1247.447 \mathrm{KN} / \mathrm{M}^{2}$ 


\section{International Journal of Engineering Applied Sciences and Technology, 2020 \\ Vol. 4, Issue 11, ISSN No. 2455-2143, Pages 410-413 \\ Published Online March 2020 in IJEAST (http://www.ijeast.com)}

\section{CONCLUSIONS}

1. Tests conducted on $\mathrm{BC}$ soil to determine the geotechnical properties showed that the $\mathrm{BC}$ soil used in the experiment was highly expansive soil with liquid limit $87.2 \%$ and plasticity index as 35.14 .

2. From the test results it was clear that the maximum MDD for Metakaolin was achieved at $30 \%$ and for cement and flyash the maximum MDD was achieved at $10 \%$.

3. Tests conducted on BC soil blended with individual stabiliser with varying percentage such as $10 \%, 20 \%$, and $30 \%$, optimum value for dry density was obtained at $30 \%$ of the blend.

4. Hence in the ternary blend, minimum amount of the stabiliser to be considered was, the sum of all stabilizers was $10 \%$ and sum of all the stabiliser, maximum was $30 \%$.

5. The above results were used to prepare a bed of $2 \mathrm{mX}$ $2 \mathrm{mX} 1.5 \mathrm{~m}$ and the sample extracted was used to determine the shear parameters to calculate the SBC of the soil.

6 . From the test result calculation it was observed that the $\mathrm{Qu}=1247.44 \mathrm{KN} / \mathrm{M}^{2}$ which is a good result.

7. From all the above points it can be concluded that the ternary blend can be used for stabilising BC soil for improving its bearing capacity.

\section{REFERANCES}

[1] Andromalos K.B., Hegazy Y.A, Jasperse B.H. (2000): "Stabilization of soft soils by soil mixing". Proceedings of the Soft Ground Technology Conference, Noorwijkerout, Netherland.

[2] Koncagül. C.E., Santi M.P. (1999): "Predicting the unconfined compressive strength of the Breathitt shale using Slakedurability, Shore hardness and rock structural properties". International Journal of Rock Mechanics and Mining Sciences 36: 139-153.

[3] Bell F.G. (1978): Foundation Engineering in Difficult Ground. Butterworths, London.

[4] ErdalCokca(2001)."'Use of Class C Fly Ashes for the Stabilization - of an Expansive Soil". Journal of Geotechnical and Geoenvironmental Engineering Vol. 127, July, pp. 568573.

[5] Pandian, N.S. Krishna, K.C.\&Leelavathamma B, (2002): "Effect of Fly Ash on the CBR Behaviour of Soils" Indian Geotechnical Conference, Allahabad, Vol.1, pp.183-186.

[6] PhanikumarB.R.\&RadheyS.Sharma(2004): "Effect of flyash on engineering properties of Expansive Soil". Journal of Geotechnical and Geoenvironmental Engineering Vol. 130, no 7, July, pp. 764-767.

[7] Salvado, S. (1995): "Pozzolanic properties of FlashCalcined Kaolinite: a comparative study with soak-Calcined products", Cement and Concrete Research. 25 (1): pp. $102-$ 112.

[8] Hassnen M. Jafer, William Atherton, MonowerSadiqueFelicite Ruddock, and Edward Loffil(2018): "Development of a new ternary blended cementitious binder produced from waste materials for use in soft soil stabilisation". Journal of Cleaner Production 172 (2018) 516-528

[9] "Soil mechanics and Foundations" by B.C Punmia , Ashok .K.Jain and Arun K Jain. 